Check for updates

Cite this: RSC Adv., 2017, 7, 22936

Received 24th January 2017

Accepted 26th March 2017

DOI: $10.1039 / c 7 r a 01065 f$

rsc.li/rsc-advances

\section{Fabrication of PEBA/ $\mathrm{Cu}_{2} \mathrm{O}$ mixed-matrix membranes and their application in pyridine recovery from aqueous solution}

\author{
Jian Hua Chen, (D) *ab Zhen Bo Su, ${ }^{a}$ Jing Ping $X u^{,}{ }^{a}$ Li Jing Lin, ${ }^{a}$ Xin Fei Dong, ${ }^{a}$ \\ Qian Peng, ${ }^{a}$ Ya San $\mathrm{He}^{a}$ and Yu Jing Nie ${ }^{a}$
}

\begin{abstract}
The lone pair of electrons of the pyridine nitrogen atom can form a complex with some metal ions such as $\mathrm{Cu}^{+}, \mathrm{Ag}^{+}$, etc. Therefore, in this paper, $\mathrm{Cu}_{2} \mathrm{O}$ nanocrystal particles were synthesized and incorporated into polyether-block-amides (PEBA) to prepare novel PEBA/ $\mathrm{Cu}_{2} \mathrm{O}$ mixed-matrix membranes (MMMs). The prepared $\mathrm{Cu}_{2} \mathrm{O} / \mathrm{PEBA}$ MMMs were characterized by Fourier-transform infrared spectrum (FTIR), $X$-ray diffraction (XRD), atomic force microscopy (AFM), scanning electron microscopy (SEM), thermogravimetric analysis (TGA) and contact angle goniometer. The effects of $\mathrm{Cu}_{2} \mathrm{O}$ incorporation on swelling and the pervaporation performance of $\mathrm{Cu}_{2} \mathrm{O} / \mathrm{PEBA}$ MMMs were evaluated with pyridine/water binary mixtures. The results indicated that the separation factor increased first, and then decreased, with increasing $\mathrm{Cu}_{2} \mathrm{O}$ content, which subsequently led to a decrease in permeation flux. The optimal performance was achieved when the weight fraction of $\mathrm{Cu}_{2} \mathrm{O}$ in the $\mathrm{PEBA} / \mathrm{Cu}_{2} \mathrm{O}$ MMMs was $6.0 \mathrm{wt} \%$ with a flux of $89.3 \mathrm{~g} \mathrm{~m}^{-2} \mathrm{~h}^{-1}$ (decreased by $13.1 \%$ compared with the pristine PEBA membrane) and separation factor of 10.22 (increased by $22.8 \%$ compared with the pristine PEBA membrane) for a 1.0 $w t \%$ pyridine aqueous solution at $30{ }^{\circ} \mathrm{C}$. The influence of process parameters such as feed temperature and feed pyridine concentration on pervaporation performance were also investigated. This work demonstrated that $\mathrm{PEBA} / \mathrm{Cu}_{2} \mathrm{O}$ MMMs could be considered as potential candidates for practical pyridine production recovery.
\end{abstract}

\section{Introduction}

Nowadays, environmental crisis is one of the major global issues due to the extensive discharge of pollutants. Pyridine is a basic heterocyclic organic compound with a pungent and disagreeable odour. It is also an important solvent widely used in the manufacture of different pharmaceutical compounds, vitamins, pesticides, paints, rubber products, and adhesives. ${ }^{1}$ The United States Environmental Protection Agency (US EPA) considers pyridine as a hazardous chemical with a high degree of toxicity and potential carcinogenicity. ${ }^{2,3}$ Pyridine compounds are introduced to the environment as effluents from different industries such as pesticides, dyes, household chemicals, feed additives, rubber chemicals and others., ${ }^{\mathbf{4} 5}$ The recovery of pyridine from aqueous effluents is of great importance because it is often necessary to reuse this relatively expensive chemical. Various technologies, such as adsorption, chemical oxidation, ion exchange, incineration or biodegradation methods, are

${ }^{a}$ College of Chemistry and Environmental Science, Minnan Normal University, Zhangzhou 363000, China. E-mail: jhchen73@126.com; Fax: +86-596-2520035; Tel: +86-596-2591445

${ }^{b}$ Fujian Province University Key Laboratory of Modern Analytical Science and Separation Technology, Minnan Normal University, Zhangzhou 363000, China used for the removal of pyridine from wastewater. ${ }^{6-9}$ However, most conventional technologies are costly and/or energy consuming when the organic components are present in low concentrations. Therefore, it is urgent to develop a more energysaving and highly efficient technology for the recovery of pyridine from wastewaters.

Pervaporation, as an environmentally friendly, highly efficient and energy-saving membrane separation process, has been widely used for the separation of azeotropic mixtures, close-boiling mixtures, low-concentration organic components from aqueous solutions, and so on. ${ }^{10-13}$ Currently, this process has been successfully commercialized in the dehydration of organic compounds; however, it still faces challenges in the removal of organic components from wastewaters. As for the reasons, first and foremost, most organic components diffuse through the membrane with more difficulty than water molecules due to the much bigger size of organic molecules. Additionally, the membranes are easily swelled or dissolved in aqueous solutions with low concentration of organics. To solve the problem mentioned above, several technologies have been investigated for the removal of organic compounds from water. $^{\mathbf{1 , 3}, 5}$ As is known to all, organophilic membranes are prepared from polymers with solubility parameters similar to one of the components, which will preferentially permeate 
through the membrane. Therefore, for selective recovery of organic components from aqueous solution, some organophilic membranes, such as polytrimethylsilylpropyne, ${ }^{\mathbf{1 4}}$ polydimethylsiloxane, ${ }^{15,16}$ styrene butadiene rubber, ${ }^{17}$ polymers of intrinsic microporosity, ${ }^{18}$ natural rubber $^{19}$ and polyvinylidene fluoride,$^{20}$ have been investigated. However, most of them show either a discouraging flux or poor selectivity for organic components. Therefore, a membrane that exhibits both good separation performance and excellent physicochemical stability is a core component for the removal of organic compounds.

Polyether-block-amide (PEBA) has a group of copolymers comprising flexible polyether (PE) segments and rigid polyamide (PA) segments. ${ }^{21-26}$ As a result, PEBA has become a promising type of membrane material. PEBA membranes have been found to exhibit a considerably high affinity to aromatic compounds from water by pervaporation. ${ }^{27,28}$ Furthermore, the preparation of PEBA-based membranes is very simple: dissolution-casting-evaporation without any cross-linking reaction, polymerization or stretching. These features are beneficial for the industrial application of PEBA membranes. Boddeker ${ }^{29}$ carried out a comparative study on pervaporation separation of four isomeric butanols through PEBA membranes. They found that the permeation flux of PEBA membrane was higher than that of PDMS and polyether-based polyurethane membranes. $\mathrm{Yen}^{30}$ found that PEBA membranes exhibited a higher butanol permeation flux than PDMS membranes. From the previously reported results, the pervaporation performance of PEBA-based membranes still do not meet the requirements for practical application. For effective recovery of pyridine from aqueous solution via pervaporation, modification of the PEBA-based membrane is thus of great importance. As we all know, $\mathrm{Cu}_{2} \mathrm{O}$ porous material, having a high specific surface area, is often used as an adsorbent for the enrichment or removal of organic contaminants from wastewater. Because the lone pair of electrons of the pyridine nitrogen atom can form a complex with some metal ions such as $\mathrm{Cu}^{+}, \mathrm{Ag}^{+}$, etc.,${ }^{30,31}$ it is expected that the addition of $\mathrm{Cu}_{2} \mathrm{O}$ inorganic particles to the PEBA matrix would enhance the adsorption ability of pyridine in the mixed-matrix membrane and improve the pyridine removal efficiency in pervaporation.

In this work, for the first time, $\mathrm{Cu}_{2} \mathrm{O}$ particles are introduced as fillers to prepare $\mathrm{PEBA} / \mathrm{Cu}_{2} \mathrm{O}$ MMMs with the aim of enhancing the selectivity of the membrane. The membrane's structure and properties were studied in detail. Pyridine/water binary mixtures were used as feed to evaluate its pervaporation performance. Moreover, the effects of $\mathrm{Cu}_{2} \mathrm{O}$ content, feed pyridine concentration, and operating temperature on the swelling and pervaporation properties of the prepared $\mathrm{Cu}_{2} \mathrm{O}$ / PEBA MMMs were also investigated.

\section{Experiment}

\subsection{Materials}

PEBA 2533 (PEBA) was purchased from Arkema, France. $N$ Methyl-2-pyrrolidone (NMP), cupric sulfate $\left(\mathrm{CuSO}_{4}\right)$, sodium hydroxide $(\mathrm{NaOH})$, ethanol $\left(\mathrm{CH}_{3} \mathrm{CH}_{2} \mathrm{OH}\right)$, and ascorbic acid were obtained from Shanghai Chemical Reagent Co. Ltd. All of the reagents were used as received without further purification.

\subsection{Synthesis of $\mathrm{Cu}_{2} \mathrm{O}$ particles}

The synthesis of highly porous $\mathrm{Cu}_{2} \mathrm{O}$ particles was accomplished using a typical synthesis process. ${ }^{32}$ In brief, $1 \mathrm{~g}$ $\mathrm{CuSO}_{4} \cdot 5 \mathrm{H}_{2} \mathrm{O}$ was dissolved into $80 \mathrm{~mL}$ of $0.1 \mathrm{M} \mathrm{NaOH}$ aqueous solution, and the resulting blue $\mathrm{Cu}(\mathrm{OH})_{2}$ precipitate was sonicated for $30 \mathrm{~min}$ to form a well-dispersed suspension. Then, $0.704 \mathrm{~g}$ of ascorbic acid was dissolved into the dispersion under vigorous stirring. After the solution turned to light yellow within $1 \mathrm{~min}$, stirring was continued for about $20 \mathrm{~min}$ at room temperature. A yellow powder product was recovered by filtration and washed several times with ethanol and deionized water. Finally, the obtained yellow solid samples were dried under vacuum at $50{ }^{\circ} \mathrm{C}$ for $6 \mathrm{~h}$, and $\mathrm{Cu}_{2} \mathrm{O}$ crystals were obtained.

\subsection{Membrane preparation}

The PEBA/ $\mathrm{Cu}_{2} \mathrm{O}$ MMMs were prepared via solution casting and solvent evaporation technique. PEBA polymer, $10 \mathrm{~g}$, was dissolved in $80 \mathrm{~mL}$ of $\mathrm{NMP}$ at $80{ }^{\circ} \mathrm{C}$ with constant stirring. Meanwhile, a definite amount of $\mathrm{Cu}_{2} \mathrm{O}$ particles were dispersed in $80 \mathrm{~mL}$ of NMP and sonicated for $60 \mathrm{~min}$. Then, the welldispersed particles were added into the previously prepared PEBA solution. Finally, the solution was further stirred vigorously for $12 \mathrm{~h}$ at $80{ }^{\circ} \mathrm{C}$ and kept overnight to release any gases. The obtained homogeneous mixed solution was poured onto a clean glass plate and heated in an oven at $70{ }^{\circ} \mathrm{C}$ for $24 \mathrm{~h}$. Then, the dried membrane was peeled off from the glass plate and further dried in a vacuum oven at $50{ }^{\circ} \mathrm{C}$ for $24 \mathrm{~h}$. The loading amount of $\mathrm{Cu}_{2} \mathrm{O}$ in the hybrid membrane was defined as:

$$
W_{\mathrm{Cu}_{2} \mathrm{O}}=\frac{M_{\mathrm{Cu}_{2} \mathrm{O}}}{M_{\mathrm{Cu}_{2} \mathrm{O}}+M_{\mathrm{PEBA}}} \times 100 \%
$$

where $M_{\text {PEBA }}$ and $M_{\mathrm{Cu}_{2} \mathrm{O}}$ represent the weights of PEBA and $\mathrm{Cu}_{2} \mathrm{O}$, respectively. The weight percent of $\mathrm{Cu}_{2} \mathrm{O}$ in the present study was varied at $0,3,6,10$ and $15 \mathrm{wt} \%$, were designated as PEBA/Cu $/ \mathrm{Cu}_{2} \mathrm{O}-0, \mathrm{PEBA} / \mathrm{Cu}_{2} \mathrm{O}-3, \mathrm{PEBA} / \mathrm{Cu}_{2} \mathrm{O}-6, \mathrm{PEBA} / \mathrm{Cu}_{2} \mathrm{O}-10$ and $\mathrm{PEBA} / \mathrm{Cu}_{2} \mathrm{O}-15$, respectively.

\subsection{Characterization of $\mathrm{Cu}_{2} \mathrm{O}$ particles and $\mathrm{PEBA} / \mathrm{Cu}_{2} \mathrm{O}$ MMMs}

The crystallographic structure of the $\mathrm{Cu}_{2} \mathrm{O}$ particles was investigated using powder X-ray diffraction (XRD, Bruker D8 Advance, $\mathrm{Cu} \mathrm{K}-\alpha$ radiation). Morphologies of the $\mathrm{Cu}_{2} \mathrm{O}$ particles, pristine PEBA membrane and PEBA/ $\mathrm{Cu}_{2} \mathrm{O}$ were observed via scanning electron microscope (JEOL, JSM-6010LA, Japan). Energy-dispersive spectrometry (EDS) elemental mapping was taken using an X-ray energy dispersion system. Thermal stability of the membranes were analyzed through thermogravimetric analysis (TGA 209 F1). To investigate the surface properties of the membrane, the static contact angles between the membranes and water were measured by the pendant drop method using a contact angle meter (SL200B, SOLON TECH, Shanghai, China) at room temperature. Atomic force microscopy (CSPM5500, China) was used to observe the morphological 
characterization and surface roughness of the prepared membranes, respectively. The Fourier-transform infrared spectra (Thermo Scientific Nicolet 8700, USA) of PEBA/ $\mathrm{Cu}_{2} \mathrm{O}-6$ MMMs before and after pervaporation were obtained with a range of $500-3500 \mathrm{~cm}^{-1}$.

\subsection{Membrane swelling and sorption study}

Swelling experiments on the membranes were performed gravimetrically in different concentrations of pyridine/water mixtures. The dried membranes were weighed and equilibrated by soaking in pyridine/water mixtures at $30{ }^{\circ} \mathrm{C}$ for $48 \mathrm{~h}$. The swollen membranes were taken out from the bottle and weighed immediately after the liquid drops on the surface of the membrane samples were wiped with filter paper. The same operation was performed at least three times for all the experiments, and the results were averaged. The error margins were less than $2.5 \%$. The percentage degree of swelling (DS \%) was determined by

$$
\operatorname{DS}(\%)=\frac{W_{\mathrm{s}}-W_{\mathrm{d}}}{W_{\mathrm{d}}} \times 100 \%
$$

where $W_{\mathrm{s}}$ and $W_{\mathrm{d}}$ denote the weights of the swollen membrane and dry membrane, respectively.

For sorption in a binary solution, the prepared membranes were immersed in $1.0 \mathrm{wt} \%$ pyridine aqueous solution at $30^{\circ} \mathrm{C}$ for $48 \mathrm{~h}$ to reach sorption equilibrium. Then, the absorbed liquid was collected in a liquid nitrogen trap by desorbing the equilibrated sample in the purge-and-trap apparatus. The concentration of the collected liquid was measured by gas chromatography equipped with TCD (packed column stationary phase GDX-102, $\mathrm{H}_{2}$ as carrier gas at $30 \mathrm{~mL} \mathrm{~min}{ }^{-1}$, sample injector temperature $120{ }^{\circ} \mathrm{C}$, column temperature $80{ }^{\circ} \mathrm{C}$ and detector temperature $150{ }^{\circ} \mathrm{C}$ ). The adsorption selectivity, $a_{\mathrm{s}}$, is expressed by

$$
a_{\mathrm{s}}=\frac{Y_{\mathrm{A}}^{\prime} / Y_{\mathrm{B}}^{\prime}}{X_{\mathrm{A}} / X_{\mathrm{B}}}
$$

where $Y_{\mathrm{A}}^{\prime}$ and $Y_{\mathrm{B}}^{\prime}$ are the mass fraction of pyridine (A) and water (B) adsorbed in the membrane; $X_{\mathrm{A}}$ and $X_{\mathrm{B}}$ are the mass fraction of pyridine and water in the binary solution, respectively.

\subsection{Pervaporation experiments}

The pervaporation experiments were conducted on a self-made equipment. Mixtures of pyridine/water ( $99: 1$, wt/wt) were used as a model solution and held in a feed tank with a volume capacity of $1 \mathrm{~L}$. The effective area of the membrane sample was $60 \mathrm{~cm}^{2}$. The downstream side of membrane was vacuumed at a pressure below 1 mbar. The system was equilibrated for $30 \mathrm{~min}$ before collecting samples. The permeate samples were collected using a cold trap immersed in liquid nitrogen. The samples were then weighted, and the compositions of the permeates were analyzed by gas chromatography. Each sample was analyzed at least three times, and thus, the data for flux and composition were achieved by averaging. The permeation flux $\left(J, \mathrm{~g} \mathrm{~m}^{-2} \mathrm{~h}^{-1}\right)$ of the membrane is defined as:

$$
J=\frac{Q}{A t}
$$

where $Q(\mathrm{~g}), A\left(\mathrm{~m}^{2}\right)$ and $t(\mathrm{~h})$ are the total weight of the permeate, the effective area of the membrane and the permeation time interval during the sample collection, respectively. The separation factor $(\alpha)$ is defined by the equation below:

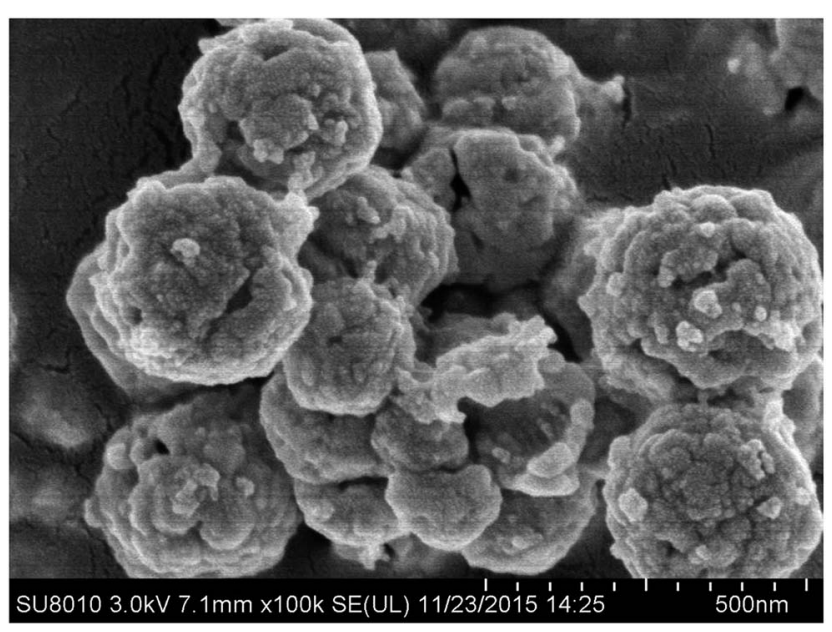

Fig. 1 SEM images of $\mathrm{Cu}_{2} \mathrm{O}$ crystal particles.
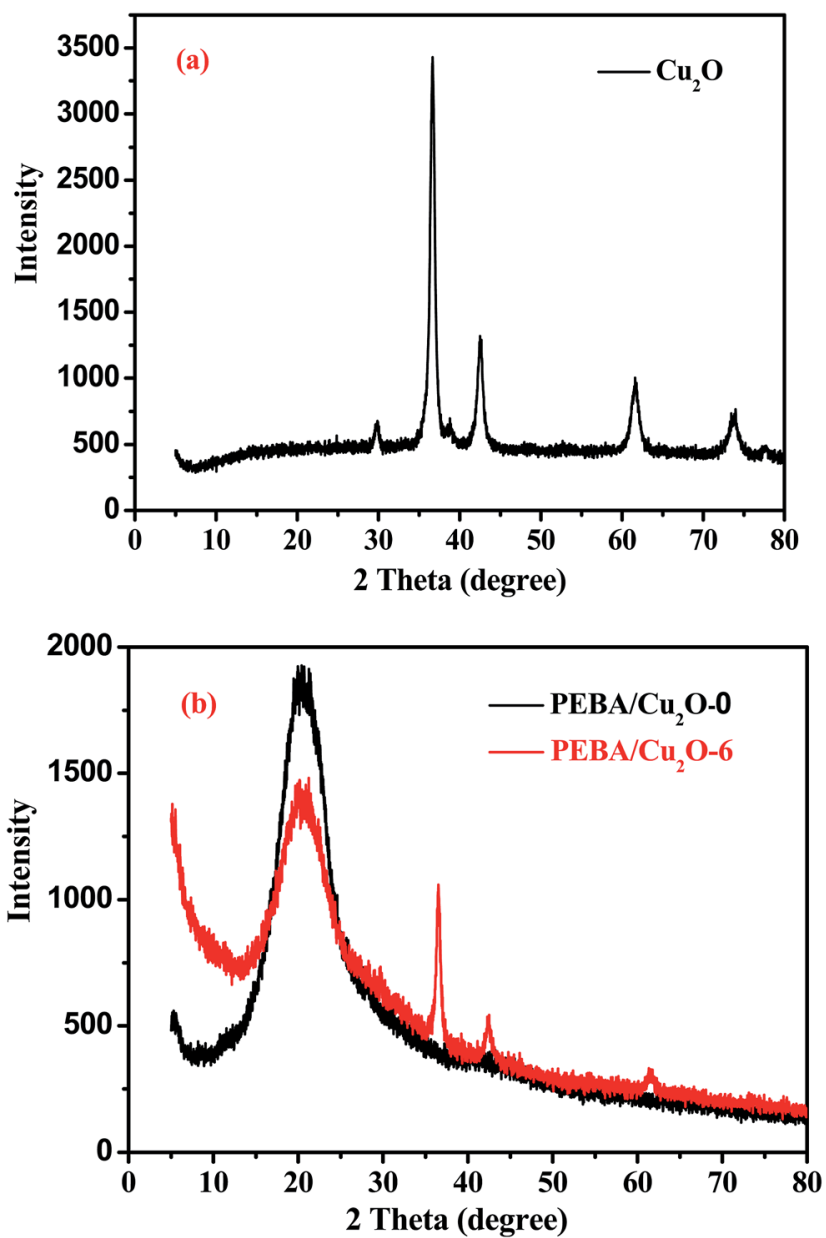

Fig. 2 XRD patterns of (a) $\mathrm{Cu}_{2} \mathrm{O}$ crystal particles and (b) PEBA/ $\mathrm{Cu}_{2} \mathrm{O}-6$ MMMs. 


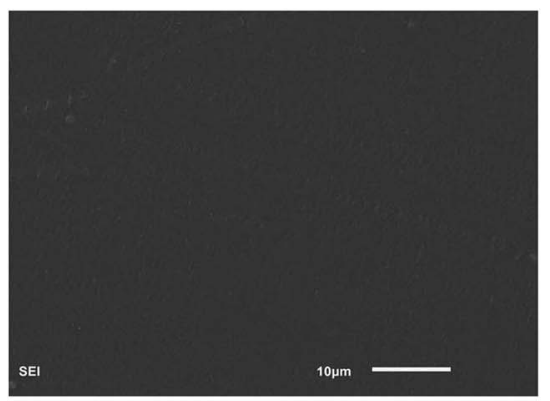

(a)

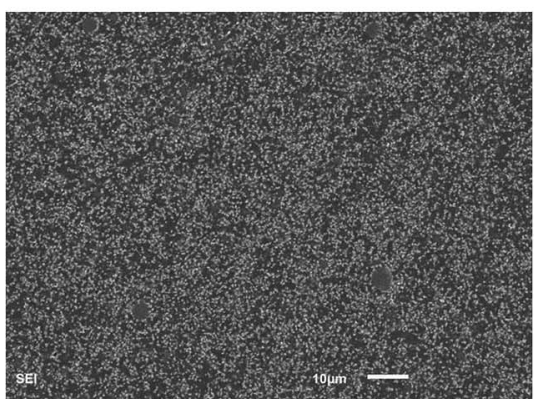

(c)

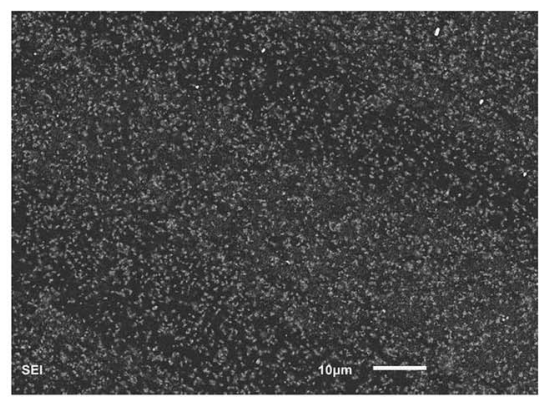

(b)

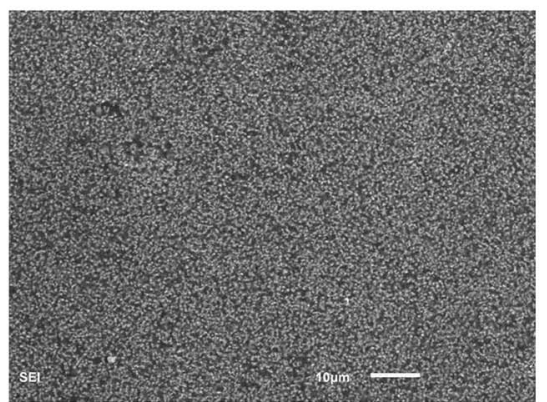

(d)

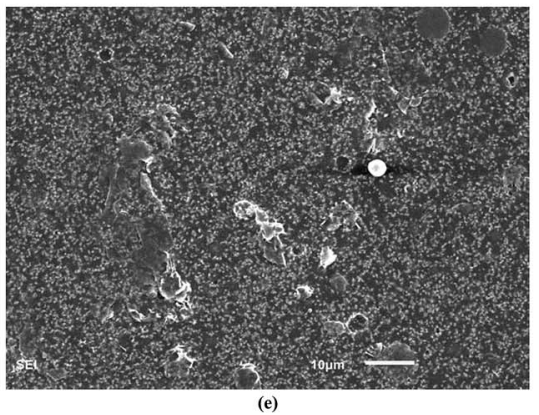

Fig. 3 SEM images of PEBA/Cu $2 \mathrm{O}$ MMMs with different $\mathrm{Cu}_{2} \mathrm{O}$ contents: (a) 0 wt\%, (b) 3 wt\%, (c) 6 wt\%, (d) 10 wt\%, (e) 15 wt\%.

$$
\alpha_{\mathrm{PV}}=\frac{Y_{\mathrm{A}} / Y_{\mathrm{B}}}{X_{\mathrm{A}} / X_{\mathrm{B}}}
$$

where $X_{\mathrm{A}}, X_{\mathrm{B}}, Y_{\mathrm{A}}$ and $Y_{\mathrm{B}}$ are the weight fractions of pyridine and water in the feed and permeate sides, respectively. According to the solution-diffusion mechanism, diffusion selectivity, $a_{\mathrm{D}}$, can be calculated as follows:

$$
a_{\mathrm{D}}=\frac{\alpha_{\mathrm{PV}}}{a_{\mathrm{s}}}
$$

The value of $\alpha_{\mathrm{PV}}$ focuses on the operating condition, while $a_{\mathrm{s}}$ reflects the property of the membrane materials.

\section{Results and discussion}

\subsection{Characterization of $\mathrm{Cu}_{2} \mathrm{O}$ crystal particles}

$\mathrm{SEM}$ of $\mathrm{Cu}_{2} \mathrm{O}$ crystal particles, as shown in Fig. 1, indicates that $\mathrm{Cu}_{2} \mathrm{O}$ crystal particles have a regular spherical shape with a size around $300 \mathrm{~nm}$, which is beneficial to fabricating well-formed hybrid membranes. XRD was also used to investigate the structure of $\mathrm{Cu}_{2} \mathrm{O}$ crystal particles. As presented in Fig. 2(a), the spectrum of synthesized $\mathrm{Cu}_{2} \mathrm{O}$ crystal particles was consistent with the results from many studies, ${ }^{32}$ indicating a highly crystalline $\mathrm{Cu}_{2} \mathrm{O}$ structure.

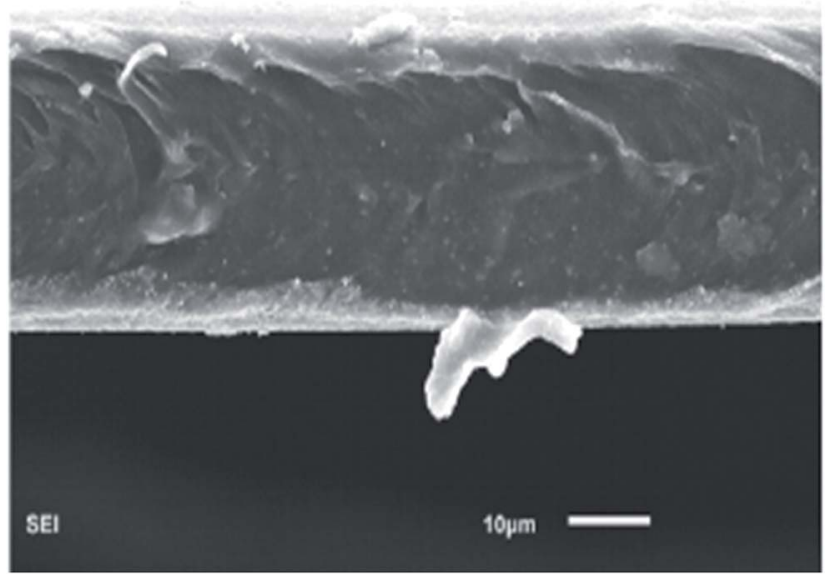

Fig. 4 SEM images of the cross-section of $\mathrm{PEBA} / \mathrm{Cu}_{2} \mathrm{O}-6 \mathrm{MMMs}$. 


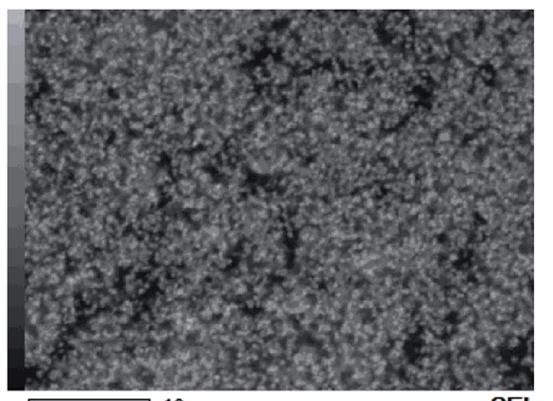

SE

(a)

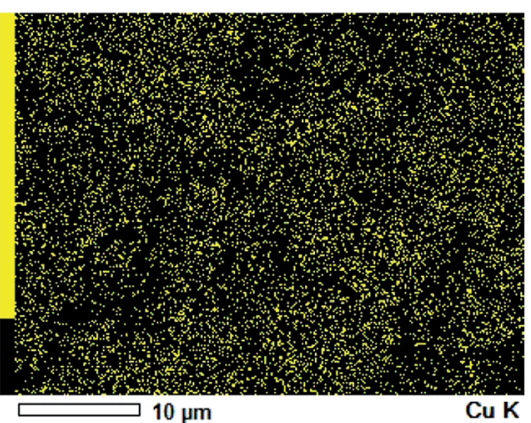

a)
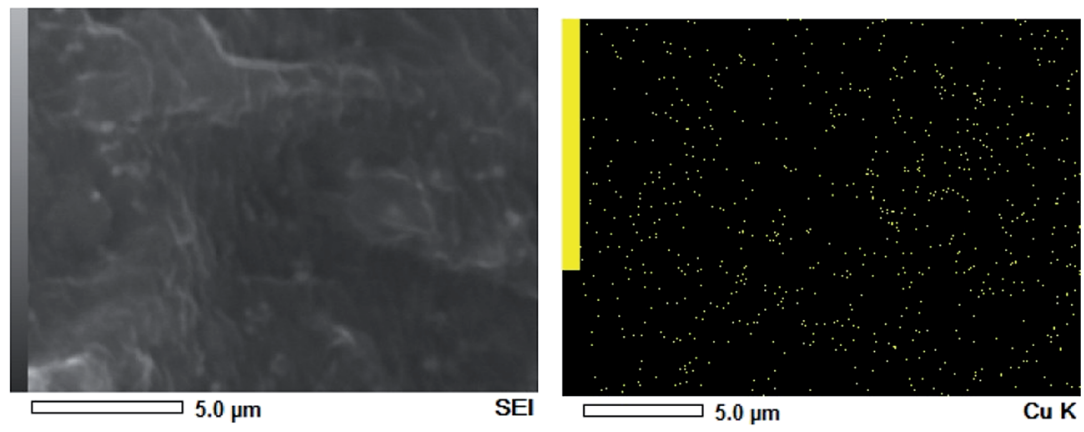

(b)

Fig. 5 X-ray spectroscopy (EDS) of PEBA/Cu $2 \mathrm{O}-6$ MMMs: (a) surface, (b) cross-section.

\subsection{Morphology of PEBA/ $\mathrm{Cu}_{2} \mathrm{O}$ MMMs}

Fig. 2(b) shows the XRD pattern of the PEBA/Cu $\mathrm{Cu}_{2} \mathrm{O}-0$ membrane. There are wide peaks at $2 \theta \approx 12-30^{\circ}$, indicating the amorphous property of the membrane. The XRD pattern of $\mathrm{PEBA} / \mathrm{Cu}_{2} \mathrm{O}-6$ MMMs shows $\mathrm{Cu}_{2} \mathrm{O}$ crystal peaks matching those of the pure $\mathrm{Cu}_{2} \mathrm{O}$ crystal particles, indicating that $\mathrm{Cu}_{2} \mathrm{O}$ crystalline structure remained unchanged after being incorporated into the PEBA matrix. The decreased intensity in the peak at $2 \theta \approx 12-30^{\circ}$ suggests a decreasing degree of crystallinity of the prepared membrane.

Further confirmation of the different morphologies of the prepared membrane was made by SEM. Fig. 3(a) shows that the surface of the pristine PEBA membrane is smooth, dense and free of defects. From Fig. 3(b) and (c), we can observe that $\mathrm{Cu}_{2} \mathrm{O}$ particles are evenly surrounded by PEBA matrix, indicating a better interfacial compatibility between them. When $\mathrm{Cu}_{2} \mathrm{O}$ content is higher than $6.0 \mathrm{wt} \%$, indicated in Fig. 3(d) and (e), $\mathrm{Cu}_{2} \mathrm{O}$ particles form a small agglomeration in the PEBA matrix. SEM image of the cross-section of PEBA/ $\mathrm{Cu}_{2} \mathrm{O}-6 \mathrm{MMMs}$ is also shown in Fig. 4. $\mathrm{Cu}_{2} \mathrm{O}$ particles are homogenously dispersed in PEBA matrix without obvious agglomeration or sedimentation, which benefits the selectivity of a pervaporation membrane.

The uniform distribution of $\mathrm{Cu}_{2} \mathrm{O}$ particles in the polymer matrix was further verified by energy-dispersive X-ray spectroscopy (EDS), as illustrated in Fig. 5. The uniformly scattered red, green and yellow points represent $\mathrm{C}, \mathrm{O}$ and $\mathrm{Cu}$ elements in the PEBA membranes, respectively.

AFM can be used to assess the changes in surface morphology and roughness of the prepared membranes. ${ }^{33}$ Compared with
SEM technique, AFM can provide the sample's tridimensional surface morphology more clearly and with higher resolution. ${ }^{34}$ Fig. 6 depicts the AFM images of pristine PEBA membrane and $\mathrm{Cu}_{2} \mathrm{O}$-filled PEBA/ $\mathrm{Cu}_{2} \mathrm{O}$ MMMs. It shows that the surface roughness of the PEBA/ $\mathrm{Cu}_{2} \mathrm{O}$ MMMs increases with increasing $\mathrm{Cu}_{2} \mathrm{O}$ content, which was in agreement with the SEM data.

Fig. 7 depicts the thermal properties of the prepared membranes under nitrogen atmosphere. At $25-300{ }^{\circ} \mathrm{C}$, the membranes were unchanged, indicating good thermal stability of the membranes. However, when the temperature was increased from $300{ }^{\circ} \mathrm{C}$ to $480{ }^{\circ} \mathrm{C}$, the $\mathrm{PEBA} / \mathrm{Cu}_{2} \mathrm{O}-6 \mathrm{MMMs}$ lost weight at a much slower rate than the PEBA pristine membrane. The thermal stability of the $\mathrm{PEBA} / \mathrm{Cu}_{2} \mathrm{O}-6$ MMMs was improved slightly.

Fig. 8 shows the spectra of $\mathrm{PEBA} / \mathrm{Cu}_{2} \mathrm{O}-6 \mathrm{MMMs}$ before and after pervaporation. The band at $1640 \mathrm{~cm}^{-1}$ is attributed to the stretching vibration of the $\mathrm{H}-\mathrm{N}-\mathrm{C}=\mathrm{O}$ group. The peak at 1100 $\mathrm{cm}^{-1}$ is assigned to the stretching vibration of $\mathrm{C}-\mathrm{O}-\mathrm{C}$ group. ${ }^{35}$ For PEBA/ $\mathrm{Cu}_{2} \mathrm{O}-6 \mathrm{MMMs}$ before pervaporation, the peak at 626 $\mathrm{cm}^{-1}$ is attributed to the stretching vibration of $\mathrm{Cu}-\mathrm{O}$ bond. ${ }^{36}$ However, for $\mathrm{PEBA} / \mathrm{Cu}_{2} \mathrm{O}-6 \mathrm{MMMs}$ after pervaporation, the stretching vibration of $\mathrm{Cu}-\mathrm{O}$ bond was shifted to $623 \mathrm{~cm}^{-1}$. This may be attributed to the pyridine nitrogen atom forming a complex with $\mathrm{Cu}_{2} \mathrm{O}$ particles.

The water contact angle of a membrane can be used to determine its hydrophilicity. ${ }^{37,38}$ The larger the contact angle, the stronger hydrophobicity will be for the membrane. As shown in Fig. 9, the higher the $\mathrm{Cu}_{2} \mathrm{O}$ content, the more hydrophobic is the membrane. This is attributed to the hydrophobic nature of $\mathrm{Cu}_{2} \mathrm{O}$ 


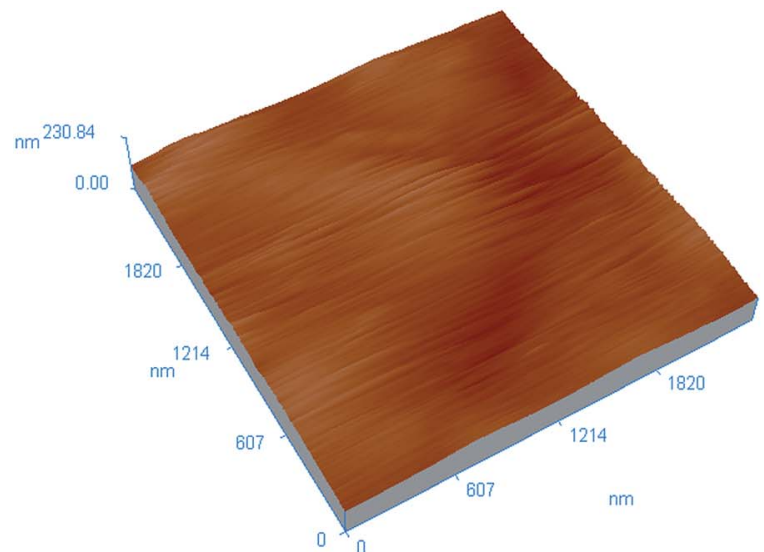

(a)

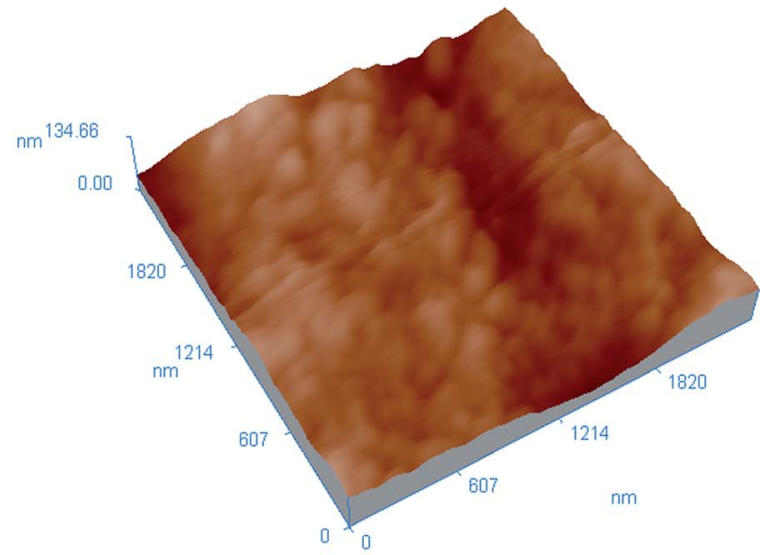

(c)

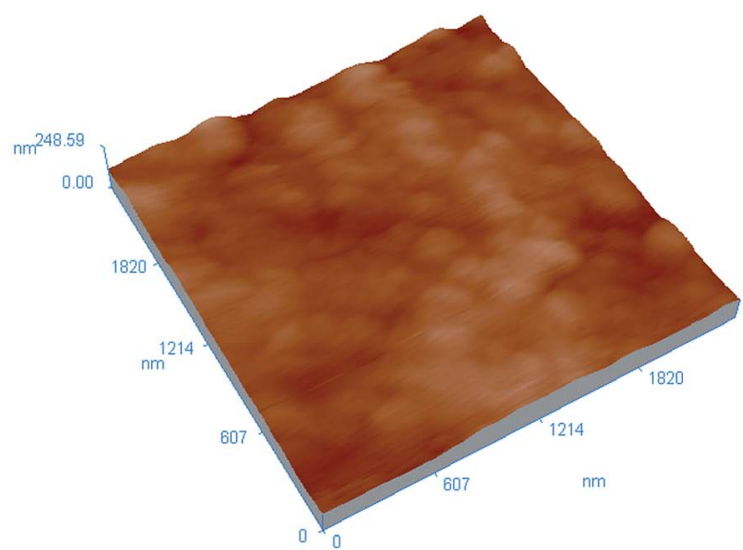

(b)

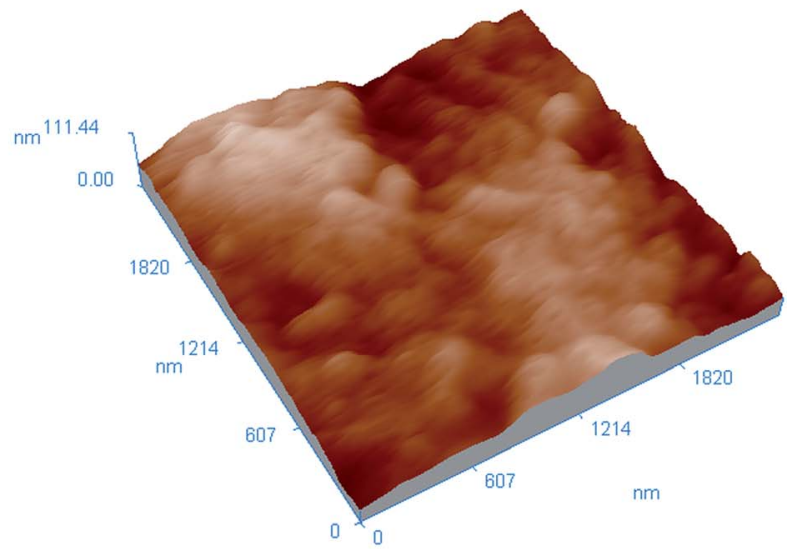

(d)

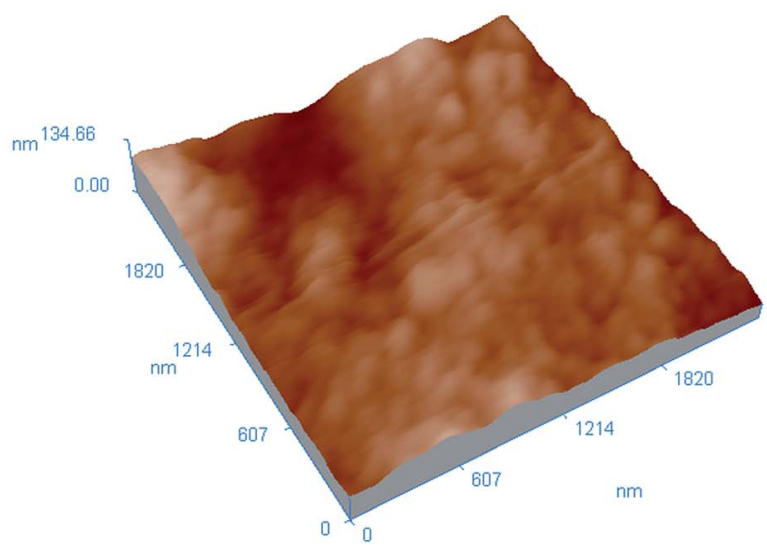

(e)

Fig. 6 AFM images of PEBA/Cu${ }_{2} \mathrm{O}$ MMMs with different $\mathrm{Cu}_{2} \mathrm{O}$ contents: (a) 0 wt\%, (b) 3 wt\%, (c) 6 wt\%, (d) 10 wt\%, (e) 15 wt\%.

as well as the increased surface roughness caused by the introduction of $\mathrm{Cu}_{2} \mathrm{O}$ particles into the PEBA matrix.

\subsection{Swelling and sorption behavior of $\mathrm{PEBA} / \mathrm{Cu}_{2} \mathrm{O} \mathrm{MMMs}$}

Swelling behavior is an important factor that affects membrane pervaporation performance. The equilibrium swelling degree (DS) of pristine PEBA membrane and PEBA/ $\mathrm{Cu}_{2} \mathrm{O}-6 \mathrm{MMMs}$ in
$1.0 \mathrm{wt} \%$ pyridine aqueous at $30{ }^{\circ} \mathrm{C}$ was investigated. As shown in Fig. 10, the incorporation of $\mathrm{Cu}_{2} \mathrm{O}$ increases the DS of membranes when the content of $\mathrm{Cu}_{2} \mathrm{O}$ increases from $0 \mathrm{wt} \%$ to $6.0 \mathrm{wt} \%$. This is attributed to the incorporation of $\mathrm{Cu}_{2} \mathrm{O}$ particles, which increased the sorption capacity of $\mathrm{PEBA} / \mathrm{Cu}_{2} \mathrm{O}$ MMMs in aqueous pyridine solution. Moreover, the packing of PEBA chain segments are interrupted by the $\mathrm{Cu}_{2} \mathrm{O}$ particles; 


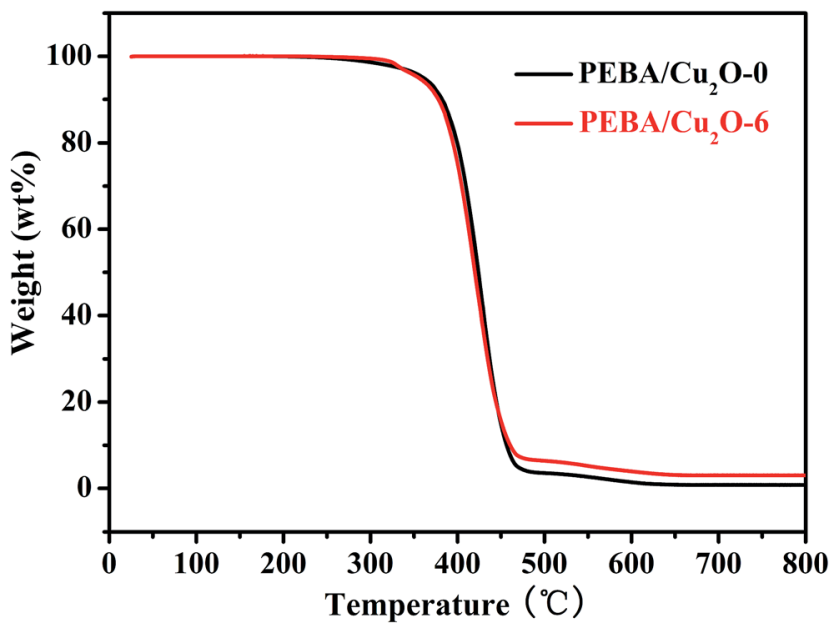

Fig. 7 The thermal properties of the pristine PEBA membrane and $\mathrm{PEBA} / \mathrm{Cu}_{2} \mathrm{O}-6 \mathrm{MMMS}$

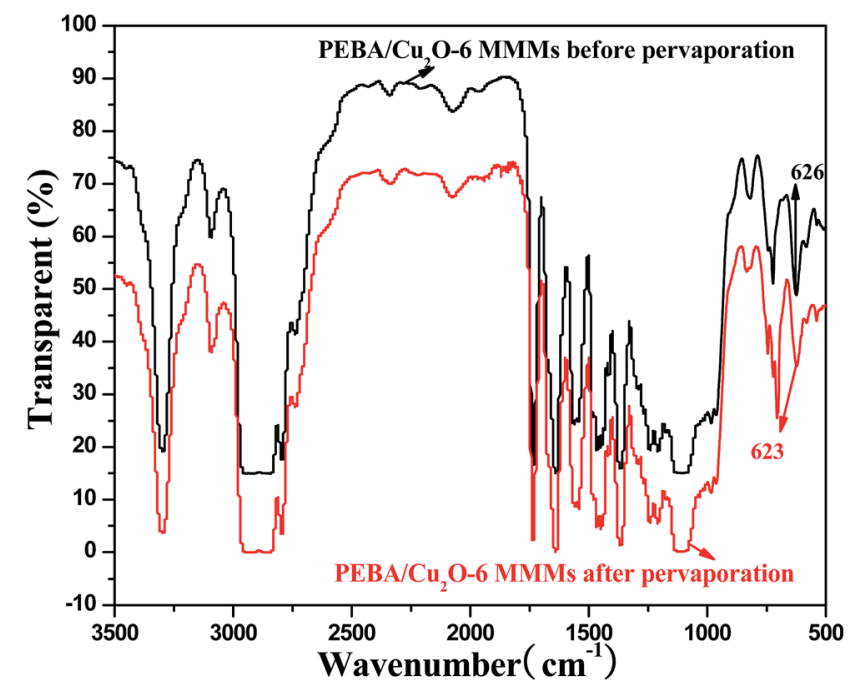

Fig. 8 Infrared spectra of PEBA/Cu $2 \mathrm{O}-6$ MMMs before and after pervaporation.

therefore, extra cavity for thermal motion of the PEBA chains is generated at the interface between the PEBA matrix and $\mathrm{Cu}_{2} \mathrm{O}$ particles, increasing the DS of PEBA/ $\mathrm{Cu}_{2} \mathrm{O}$ MMMs. When the $\mathrm{Cu}_{2} \mathrm{O}$ particle content further increases to $15.0 \mathrm{wt} \%$, aggregation of the particles becomes dominant, part of PEBA chains segments are confined in the aggregates, and thus the polymer network is extruded and becomes rigid. As a result, the swelling of PEBA matrix is reduced.

In a pervaporation process, transport behaviors of penetrant molecules are generally described by the solution-diffusion mechanism..$^{39,40}$ Thus, sorption selectivity $\left(a_{\mathrm{s}}\right)$ and diffusion selectivity $\left(a_{\mathrm{D}}\right)$ characteristics of the membrane were explored and are shown in Fig. 11. The values of $a_{\mathrm{s}}$ increase notably with increasing $\mathrm{Cu}_{2} \mathrm{O}$ content up to $6 \mathrm{wt} \%$. This is attributed to the pyridine nitrogen atom forming a complex with $\mathrm{Cu}_{2} \mathrm{O}$ particles, hence increasing the sorption capacity of $\mathrm{PEBA} / \mathrm{Cu}_{2} \mathrm{O} \mathrm{MMMs}$ for pyridine in the feed and decreasing the sorption property of the

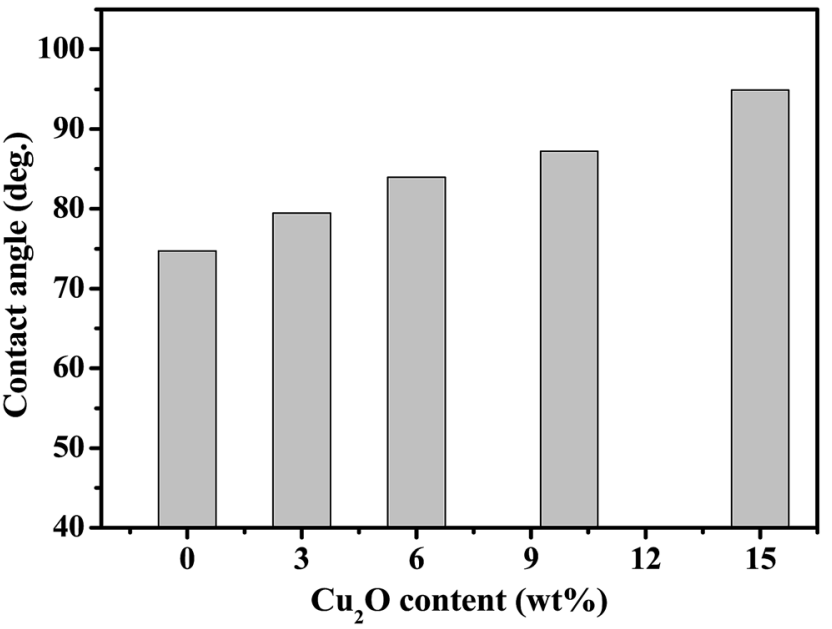

Fig. 9 Effect of $\mathrm{Cu}_{2} \mathrm{O}$ content on water contact angle of the membrane.

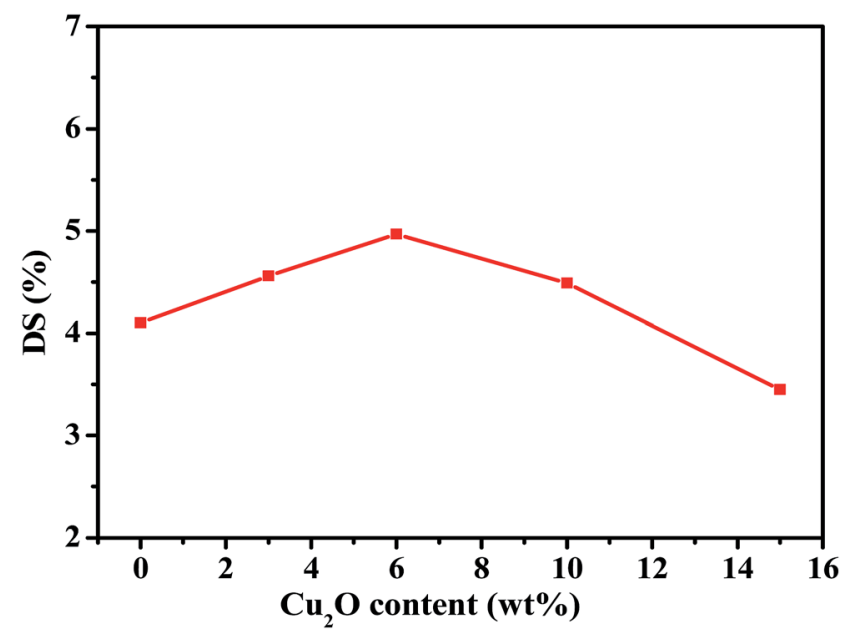

Fig. 10 Swelling behavior of PEBA/Cu $2 \mathrm{O}$ MMMs with different $\mathrm{Cu}_{2} \mathrm{O}$ contents in $1.0 \mathrm{wt} \%$ pyridine aqueous solution at $30{ }^{\circ} \mathrm{C}$.

membrane for water. However, the $\mathrm{Cu}_{2} \mathrm{O}$ particle aggregation at higher $\mathrm{Cu}_{2} \mathrm{O}$ content creates voids between the $\mathrm{Cu}_{2} \mathrm{O}$ particle and PEBA matrix, which become non-selective transport paths for pyridine and water molecules. As a result, the values of $a_{\mathrm{s}}$ decrease with the further increase of $\mathrm{Cu}_{2} \mathrm{O}$ content. This trend is the same as that observed in the swelling experiments. From Fig. 11, we observe that the value of $a_{\mathrm{D}}$ slightly decreases with increasing $\mathrm{Cu}_{2} \mathrm{O}$ content from $0 \mathrm{wt} \%$ to $15.0 \mathrm{wt} \%$. This was ascribed to the increase of mass transfer resistance within membranes due to the incorporation of $\mathrm{Cu}_{2} \mathrm{O}$ particles. Meanwhile, the kinetic diameter of pyridine molecules is much larger than that of water molecules, which was detrimental to the diffusion of pyridine molecules through the membrane.

\subsection{Effects of operation conditions on the pervaporation}

3.4.1. Effect of $\mathrm{Cu}_{2} \mathrm{O}$ content on pervaporation performance. The effect of $\mathrm{Cu}_{2} \mathrm{O}$ content on pervaporation performance is shown in Fig. 12. The decrease in permeation flux could be 


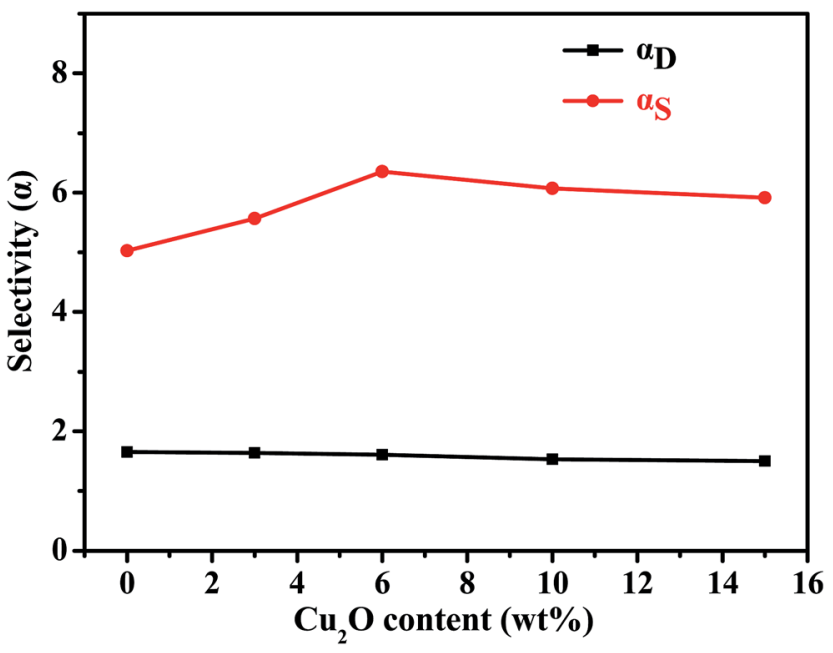

Fig. 11 Sorption and diffusion behavior of PEBA/Cu $\mathrm{Cu}_{2} \mathrm{OMMs}$ with different $\mathrm{Cu}_{2} \mathrm{O}$ contents in $1.0 \mathrm{wt} \%$ pyridine aqueous solution at $30^{\circ} \mathrm{C}$.

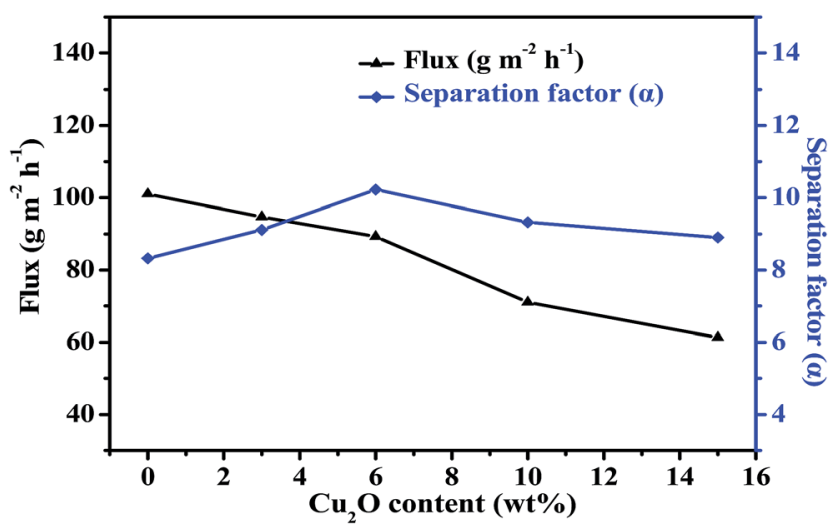

Fig. 12 Effect of $\mathrm{Cu}_{2} \mathrm{O}$ content on pervaporation performance of the $\mathrm{PEBA} / \mathrm{Cu}_{2} \mathrm{O} \mathrm{MMMs}$ in the pervaporation of $1.0 \mathrm{wt} \%$ pyridine aqueous solution at $30{ }^{\circ} \mathrm{C}$.

responsible for the tortuous effect of $\mathrm{Cu}_{2} \mathrm{O}$ incorporation. Due to $\mathrm{Cu}_{2} \mathrm{O}$ incorporation, the polymer chain motion was limited, and the free diffusion of penetrants was hindered. Thereby, the penetrants have to go through longer diffusion pathways around $\mathrm{Cu}_{2} \mathrm{O}$ particles, consequently decreasing the diffusivities of the penetrants. ${ }^{41}$ In addition, the hydrophobicity of the $\mathrm{PEBA} / \mathrm{Cu}_{2} \mathrm{O}$ MMMs increases when $\mathrm{Cu}_{2} \mathrm{O}$ content increases from 0 to 15.0 wt\% (as shown by the water contact angle in Fig. 9). As is well known, the separation selectivity of a membrane is determined by both sorption selectivity and diffusion selectivity. When the $\mathrm{Cu}_{2} \mathrm{O}$ particles was incorporated into PEBA membranes, a strong complex was formed between the $\mathrm{Cu}^{+}$within the membranes and the lone pair of electrons of the pyridine nitrogen atom, ${ }^{31,42,43}$ which benefits the sorption selectivity. However, the $\mathrm{Cu}_{2} \mathrm{O}$ particle aggregation at higher contents created voids between the $\mathrm{Cu}_{2} \mathrm{O}$ particle and PEBA matrix, which become non-selective transport paths for pyridine and water, thus harming diffusion selectivity. Therefore, the separation selectivity first increases because of the enhanced sorption capacity of pyridine by $\mathrm{PEBA} / \mathrm{Cu}_{2} \mathrm{O} \mathrm{MMMs}$ and then decreases due to non-selective transport paths for pyridine

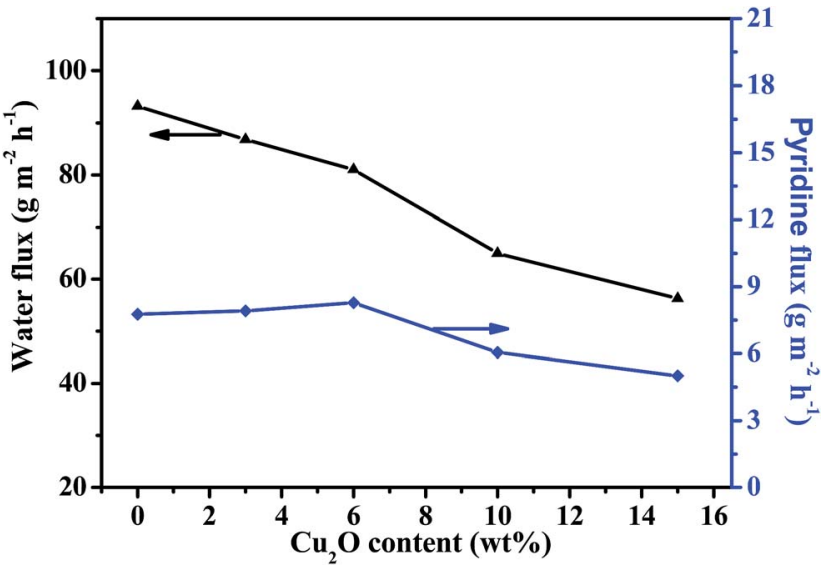

Fig. 13 Effect of $\mathrm{Cu}_{2} \mathrm{O}$ content on pyridine flux and water flux of the $\mathrm{PEBA} / \mathrm{Cu}_{2} \mathrm{O} \mathrm{MMMs}$ in the pervaporation of $1.0 \mathrm{wt} \%$ pyridine aqueous solution at $30{ }^{\circ} \mathrm{C}$.

and water becoming dominant with a further increase of $\mathrm{Cu}_{2} \mathrm{O}$ content. The pyridine flux and water flux were also calculated. According to Fig. 13, the value of pyridine flux slightly increases with increasing $\mathrm{Cu}_{2} \mathrm{O}$ particle content up to $6.0 \mathrm{wt} \%$, but then decreases with further increase, and the water flux decreases with increasing $\mathrm{Cu}_{2} \mathrm{O}$ content. As a result, $\mathrm{PEBA} / \mathrm{Cu}_{2} \mathrm{O}-6 \mathrm{MMMs}$ were chosen for use in further studies of pyridine recovery.

3.4.2. Effect of feed temperature on pervaporation performance. The effect of temperature on the separation performance of the PEBA/ $\mathrm{Cu}_{2} \mathrm{O}-6$ MMMs was investigated and is revealed in Fig. 14. The results show that both the total flux and separation factor of membranes increase with increased feed temperature. These behaviors can be attributed to the increased thermal movement of PEBA polymer chains with increased temperature, therefore resulting in an increase of free volume, which reduces the diffusion resistance of the membranes for penetrants and leads to increased permeability. Moreover, saturated vapor pressure of the feed in the upstream side of the membrane increases with increased feed temperature. However, the pressure at the downstream side of the membrane

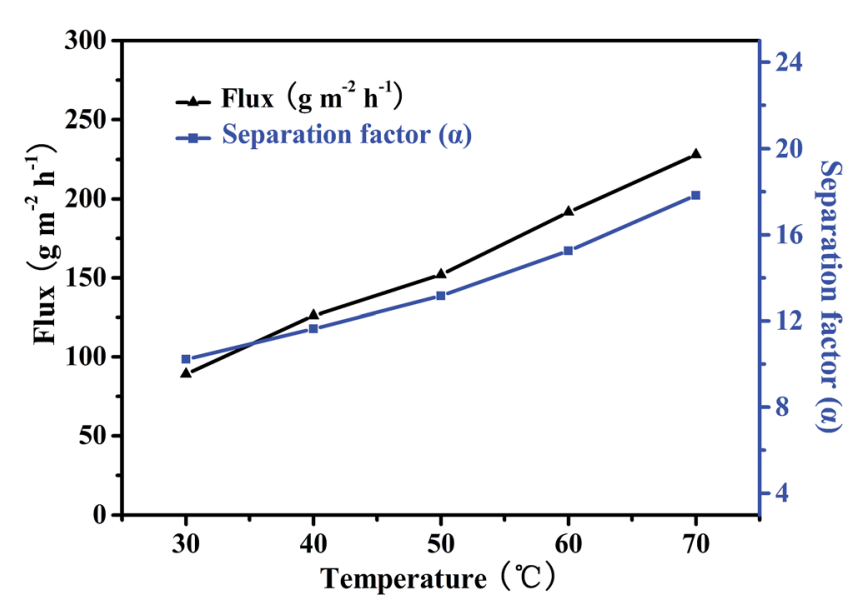

Fig. 14 Effect of feed temperature on pervaporation performance of the PEBA/ $\mathrm{Cu}_{2} \mathrm{O}-6 \mathrm{MMMs}$ in the pervaporation of $1.0 \mathrm{wt} \%$ pyridine aqueous solution. 


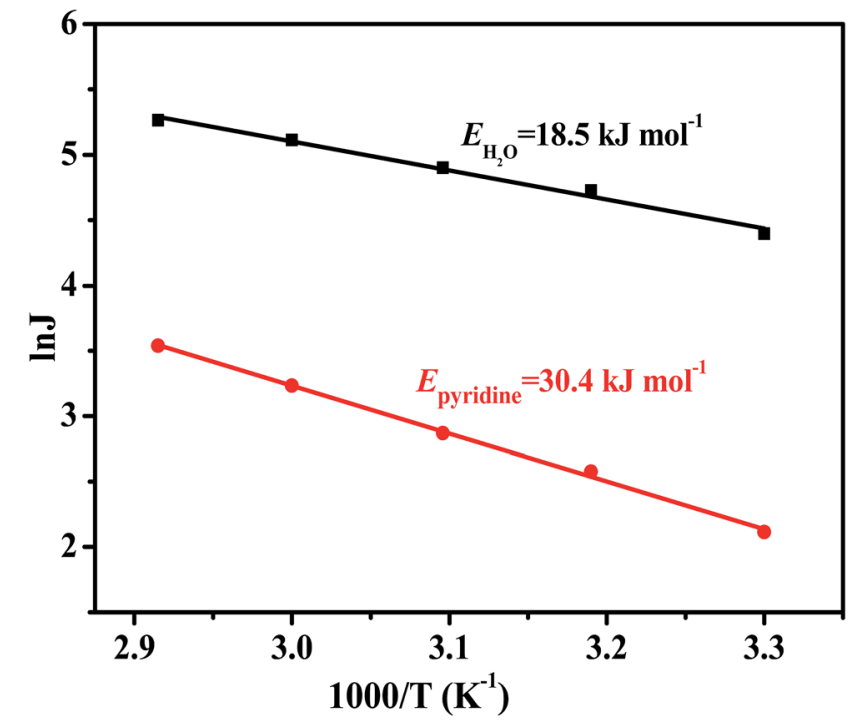

Fig. 15 Variation of $\ln \mathrm{J}$ versus $1 / T$ for the $\mathrm{PEBA} / \mathrm{Cu}_{2} \mathrm{O}-6 \mathrm{MMMs}$ in the pervaporation of $1.0 \mathrm{wt} \%$ pyridine aqueous solution.

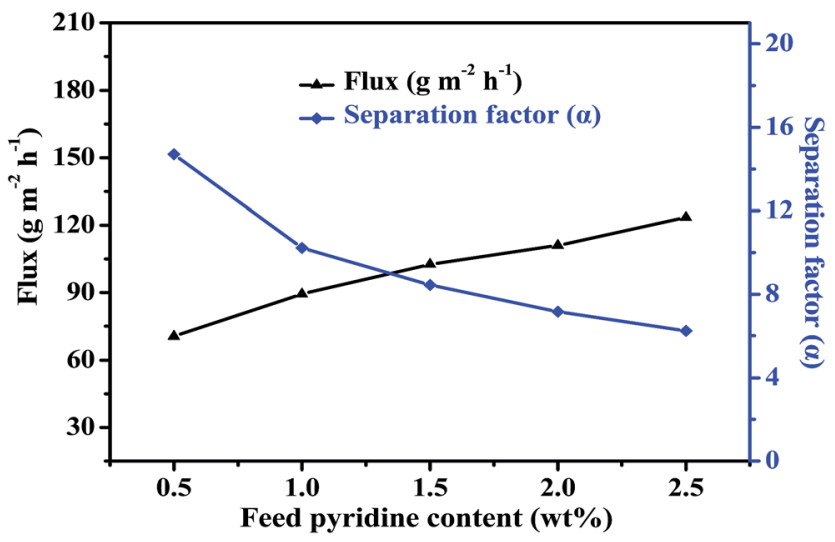

Fig. 16 Effect of feed pyridine concentration on pervaporation performance of $\mathrm{PEBA} / \mathrm{Cu}_{2} \mathrm{O}-6 \mathrm{MMMs}$ at $30^{\circ} \mathrm{C}$.

remained unchanged. Consequently, the driving force of mass transport across the membrane increased, and this could also contribute to the enhanced permeability. Furthermore, increasing the feed temperature also enhances the movement of pyridine and water molecules, which makes it easy for both molecules to diffuse through the membranes.

The relationship between the flux of a penetrant and the operation temperature can be evaluated by the Van't HoffArrhenius equation: ${ }^{44}$

$$
J=J_{0} \exp \left(-E_{\mathrm{p}} / R T\right)
$$

where $J, J_{0}, E_{\mathrm{p}}, R$ and $T$ are the flux, pre-exponential factor, activation energy, molar gas constant and the temperature in Kelvin. The Arrhenius plots of $\ln J$ versus $1 / T$ for the $\mathrm{PEBA} / \mathrm{Cu}_{2} \mathrm{O}$ $6 \mathrm{MMMs}$ are linear, as shown in Fig. 15. The activation energy $E_{\mathrm{p}}$ of pyridine and water are 30.4 and $18.5 \mathrm{~kJ} \mathrm{~mol}^{-1}$, respectively. As we all know, molecule permeation is inversely proportional to the Arrhenius activation energy values. Clearly, the value of $E_{\mathrm{p}}$ of water is much lower than that of pyridine, indicating that the mass transfer of pyridine is more sensitive to temperature than that of water. As a result, when operating temperature increases, the resulting increase of partial flux of pyridine is faster than that of water, hence increasing the selectivity.

3.4.3. Effect of feed pyridine concentration on pervaporation performance. The effect of feed pyridine concentration on the PEBA/ $\mathrm{Cu}_{2} \mathrm{O}-6 \mathrm{MMM}$ pervaporation performance was carried out at a given temperature. Fig. 16 shows that as feed pyridine concentration increases, the permeation flux increases, while the separation factor decreases. With the increased pyridine concentration in feed, pyridine has a higher chance to interact with PEBA/ $\mathrm{Cu}_{2} \mathrm{O}-6 \mathrm{MMMs}$, which increases the SD of the membrane, therefore resulting in an increase of free volume and then the flux. In addition, considering pyridine molecules have a relatively bigger size than water molecules, the diffusion rate of pyridine molecules through the membrane is slower than that of water molecules, therefore decreasing the separation factor of the PEBA/ $\mathrm{Cu}_{2} \mathrm{O}-6 \mathrm{MMMs}$.

3.4.4. Comparison of performance with reported data. The relative performance of different membranes used for the separation of pyridine from its mixtures with water are given in Table 1. One can find that the pervaporation performance of the PEBA/ $\mathrm{Cu}_{2} \mathrm{O}-6 \mathrm{MMMs}$ shows high flux with reasonable separation factor for pyridine in comparison with other membranes.

Table 1 Comparison of pervaporation performance of PEBA/Cu $2 \mathrm{O}-6 \mathrm{MMMs}$ with literature data at different operation conditions in water/ pyridine separation mixtures

\begin{tabular}{|c|c|c|c|c|c|}
\hline Membranes & Pyridine (wt $\%)$ & Temperature $\left({ }^{\circ} \mathrm{C}\right)$ & Flux $\left(\mathrm{g} \mathrm{m}^{-2} \mathrm{~h}^{-1}\right)$ & Separation factor & Reference \\
\hline Filled EPDM membrane & 4.79 & 60 & 28.73 & 92 & 3 \\
\hline $\begin{array}{l}\text { SBR5 (SBR with 5\% N330 carbon black } \\
\text { filler) }\end{array}$ & 0.48 & 40 & 76 & 35 & 17 \\
\hline $\begin{array}{l}\text { NR5 (NR with 5\% N330 carbon black } \\
\text { filler) }\end{array}$ & 4.89 & 40 & 73 & 33 & 18 \\
\hline $\begin{array}{l}\text { Silicalite filled silicone composite } \\
\text { membrane }\end{array}$ & 5.0 & 50 & 428 & 34 & 45 \\
\hline PDMS-PA composite & 5.0 & 35 & 904 & 26 & 47 \\
\hline PEBA/ $\mathrm{Cu}_{2} \mathrm{O}-6 \mathrm{MMMs}$ & 1.0 & 70 & 230 & 18 & Present $\mathrm{w}$ \\
\hline
\end{tabular}




\section{Conclusion}

$\mathrm{Cu}_{2} \mathrm{O}$ particle-filled PEBA mixed-matrix membranes were prepared and applied in the recovery of pyridine from dilute pyridine solution via pervaporation. Characterization using SEM and EDS mappings showed that $\mathrm{Cu}_{2} \mathrm{O}$ particles were uniformly dispersed in the polymer matrix. The pervaporation test results demonstrated that the total flux decreased with increasing $\mathrm{Cu}_{2} \mathrm{O}$ content, while the separation factor shows an initial rising and then decreasing trend. The PEBA $/ \mathrm{Cu}_{2} \mathrm{O}-6$ MMMs demonstrated the highest separation factor of 10.22 and the maximum value of pyridine flux of $8.28 \mathrm{~g} \mathrm{~m}^{-2} \mathrm{~h}^{-1}$ in the pervaporation of $1.0 \mathrm{wt} \%$ pyridine aqueous solution at $30{ }^{\circ} \mathrm{C}$. Meanwhile, the pervaporation performance of PEBA $/ \mathrm{Cu}_{2} \mathrm{O}-6$ MMMs showed that the positive effects of feed temperature and concentration on membrane separation performance have great significance in engineering applications. In summary, the PEBA/ $\mathrm{Cu}_{2} \mathrm{O}$ MMMs have great potential for application in the pervaporation removal of pyridine from aqueous solutions.

\section{Acknowledgements}

The authors would like to acknowledge the financial support of this work from National Natural Science Foundation of China (No. 21676133) and Natural Science Foundation of Fujian (No. 2014J01051). The authors also thank the anonymous referees for comments on this manuscript.

\section{References}

1 A. G. Yewale, N. D. Patil and A. W. Patwardhan, Desalin. Water Treat., 2015, 1.

2 M. Reháková, F. Ľubica and Z. Bastl, J. Hazard. Mater., 2011, 186, 699.

3 N. R. Singha, P. Das and S. K. Ray, J. Ind. Eng. Chem., 2013, 19, 2034.

4 D. H. Lataye, I. M. Mishra and I. D. Mall, Ind. Eng. Chem. Res., 2006, 45, 3934.

5 D. Mohan, K. P. Singh, S. Sinha, et al., Carbon, 2004, 42, 2409.

6 D. H. Lataye, I. M. Mishra and I. D. Mall, Ind. Eng. Chem. Res., 2006, 45, 3934.

7 A. K. Mathur, C. B. Majumder, S. Chatterjee and P. Roy, J. Hazard. Mater., 2008, 157, 335.

8 S. Fetzner, Appl. Microbiol. Biotechnol., 1998, 49, 237.

9 S. T. Lee, T. K. Rhee and G. M. Lee, Appl. Environ. Microbiol., 1994, 41, 652.

10 Y. Wang, T. S. Chung and H. Wang, AIChE J., 2011, 57, 1470.

11 S. Claes, P. Vandezande, S. Mullens, et al., J. Membr. Sci., 2012, 389, 459.

12 X. S. Feng and R. Y. M. Huang, Liquid separation by membrane pervaporation: a review, Ind. Eng. Chem. Res., 1997, 36, 1048.

13 S. Yu, F. Pan, S. Yang, et al., Chem. Eng. Sci., 2015, 135, 479.

14 J. R. Gonziilez-Velasco, J. A. Gonzilez-Marcos and C. LbpezDehesa, Desalination, 2002, 149, 61.

15 E. Drioli, S. M. Zhang, A. B. E. Drioli and S. A. B. Zhang, J. Membr. Sci., 1993, 80, 309.
16 T. Uragami, T. Ohshima and T. Miyata, Macromolecules, 2003, 36, 9430.

17 N. R. Singha, S. K. Ray and B. B. Konar, J. Appl. Polym. Sci., 2011, 121, 1330.

18 N. R. Singha and S. K. Ray, J. Appl. Polym. Sci., 2012, 124, 99.

19 X. M. Wu, Q. G. Zhang, F. Soyekwo, et al., AIChE J., 2016, 62, 842.

20 M. Khayet, G. Chowdhury and T. Matsuura, AIChE J., 2002, 48, 2833.

21 F. F. Liu, L. Liu and X. S. Feng, Sep. Sci. Technol., 2005, 42, 273.

22 E. A. Fouad and X. S. Feng, J. Membr. Sci., 2008, 323, 428.

23 N. L. Le, Y. Wang and T. S. Chung, J. Membr. Sci., 2011, 379, 174.

24 J. Gu, X. Shi, Y. Bai, et al., Chem. Eng. Technol., 2009, 32, 155.

25 K. W. Boddeker, G. Bengtson and H. Pingel, J. Membr. Sci., 1990, 54, 1.

26 H. W. Yen, S. F. Lin and I. K. Yang, Bioresour. Technol., 2012, 133, 372.

27 P. Sampranpiboon, R. Jiraratananon, R. Y. M. Huang, et al., J. Membr. Sci., 2000, 173, 53.

28 M. K. Djebbar, Q. T. Nguyen, R. Clement and Y. Germain, J. Membr. Sci., 1998, 146, 125.

29 K. W. Boddeker, G. Bengtson and H. Pingel, J. Membr. Sci., 1990, 54, 1.

30 H. W. Yen, S. F. Lin and I. K. Yang, J. Biosci. Bioeng., 2012, 113, 372.

31 F. Benaliouche, Y. Boucheff, P. Ayrault, et al., Microporous Mesoporous Mater., 2008, 111, 80.

32 J. Liu, Z. Gao and H. Han, Chem. Eng. J., 2012, 185, 151.

33 S. Panahian, A. Raisi, A. Aroujalian, et al., Desalination, 2015, $355,45$.

34 J. H. Chen, J. Z. Zheng and Q. L. Liu, J. Membr. Sci., 2013, 429, 206.

35 S. N. Liu, G. P. Liu, X. H. Zhao and W. Q. Jin, J. Membr. Sci., 2013, 446, 181.

36 Y. Yu, L. L Ma, W. Y Huang, et al., J. Solid State Chem., 2005, 178, 1488.

37 Z. B. Su, J. H. Chen, X. Sun, et al., RSC Adv., 2015, 5, 99008.

38 S. J. Lue, J. S. Ou, C. H. Kuo, et al., J. Membr. Sci., 2010, 347, 108.

39 E. E. B. Meuleman, B. Bosch, M. H. V. Mulder, et al., AIChEJ., 1999, 45, 2153.

40 R. B. Qi, Y. J. Wang, J. D. Li, et al., Sep. Purif. Technol., 2007, 57, 170.

41 X. Feng and R. Y. M. Huang, J. Membr. Sci., 1996, 118, 127.

42 A. J. Hallett, T. M. O'Brien, E. Carter, et al., Inorg. Chim. Acta, 2016, 441, 86.

43 S. Demir, H. M. Çepni, N. Bilgin, et al., Polyhedron, 2016, 115, 236.

44 V. T. Magalad, G. S. Gokavi, V. S. N. RajuK and T. M. Aminabhavi, J. Membr. Sci., 2010, 354, 150.

45 P. C. Joyce, K. M. Devine and C. S. Slater, Sep. Sci. Technol., 1995, 30, 2145.

46 M. K. Mandal and P. K. Bhattachary, J. Membr. Sci., 2006, 286, 115.

47 C. Chen, Z. Xiao, K. Deng, et al., Sep. Sci. Technol., 2013, 48, 1252. 